\title{
PELATIHAN DAN PEMBUATAN ECOBRICK UNTUK MEMFASILITASI RUMAH BELAJAR SEKAR
}

\author{
Chandra Suryani Rahendaputri $\left.{ }^{1}\right)$, Budiani Fitria Endrawati ${ }^{1)}$, Marita Wulandari ${ }^{11}$ \\ 1)Program Studi Teknik Lingkungan, Institut Teknologi Kalimantan, Balikpapan, Kalimantan Timur, Indonesia \\ Corresponding Author: Chandra Suryani Rahendaputri \\ Email: chandra.suryani03@lecturer.itk.ac.id
}

Diterima 22 Oktober 2020, Direvisi 31 Oktober 2020, Disetujui 01 November 2020

\begin{abstract}
ABSTRAK
Pengabdian masyarakat ini ditujukan untuk memenuhi kebutuhan furnitur ecoclass, dengan memanfaatkan sampah yang ada di lingkungan mitra yaitu Rumah Belajar Sekar, Balikpapan. Untuk memenuhi kebutuhan furnitur ini, maka dilakukanlah sebuah pelatihan pembuatan ecobrick dalam bentuk webinar dan juga dibuatlah furnitur meja, kursi dan dinding dari ecobrick. Untuk mengetahui keberhasilan dari webinar yang telah dilaksanakan dengan jumlah peserta 16 orang, dilakukanlah pengisian questionnaire daring, sebelum dan sesudah webinar berlangsung. Dari hasil questionnaire dari webinar pelatihan pembuatan ecobrick yang telah dilakukan, didapatkan bahwa sebanyak 12 peserta dari total 16 peserta, sudah mengetahui apa itu ecobrick dan 9 diantaranya sudah mengetahui manfaat ecobrick, sebelum webinar berlangsung. Setelah webinar, dapat dilihat bahwa 16 peserta sudah mengetahui apa itu ecobrick dan apa manfaatnya. 16 peserta menyatakan tertarik untuk membuat ecobrick, namun hanya 14 yang tertarik untuk membuat furnitur ecobrick. 2 peserta mengungkapkan faktor penghambatnya adalah tidak ada waktu dan malas membuat. Dari pengabdian masyarakat ini dihasilkan 2 kursi, 1 meja dan juga 3 dinding ecobrick yang diletakkan di Rumah Belajar Sekar. Pembuatan ecobrick ini dapat menjawab permasalahan mitra untuk memenuhi kebutuhan furnitur dan juga menyelesaikan permasalahan untuk mengurangi sampah plastik.
\end{abstract}

Kata kunci: ecobrick; furnitur; pengelolaan sampah; plastik.

\begin{abstract}
This community service is aimed to meet the needs of ecoclass' furniture, by utilizing waste in the partner's environment, namely Rumah Belajar Sekar, Balikpapan. To fulfill this furniture need, an ecobrick making training was conducted in the form of a webinar. The team also made ecobrick as furniture like table, chairs and wall. To determine the results of the webinar that has been conducted with 16 participants, an online questionnaire was completed, before and after the webinar. From the questionnaire results, it was found that as many as 12 participants out of a total of 16 participants already knew what ecobrick was and 9 of them already knew the benefits of ecobricking, before the webinar took place. After the webinar, it can be seen that 16 participants already know what ecobricking was and what its benefits were. 16 participants expressed their interest in making ecobricks, but only 14 were interested in making ecobrick's furniture. 2 participants revealed that the inhibiting factors were not having enough time and lazy to make. From this community service, 2 chairs, 1 table and 3 ecobrick walls were produced which were placed in the Rumah Belajar Sekar. Making this ecobrick can answer partner's needs of furniture and also solve problems to reduce plastic waste.
\end{abstract}

Keywords: ecobrick; furniture; waste management; plastic

\section{PENDAHULUAN}

Balikpapan, salah satu kota besar di Kalimantan Timur, dengan luas wilayah 503.33 $\mathrm{km}^{2}$ dan berpenduduk sebanyak 636 Jiwa ini, menurut data yang dapat diambil dari sistem informasi pengelolaan sampah nasional dibawah naungan Kementerian Lingkungan Hidup dan Perhutanan ini menghasilkan sampah sebanyak
457.93 ton/hari. Dari jumlah ini, komposisi sampah plastik menduduki $14,41 \%$, dimana berarti ada sekitar 64,4 ton/ hari adalah sampah plastik (Kementerian Lingkungan Hidup dan Kehutanan Republik Indonesia, 2018). Sampah plastik adalah jenis sampah yang hampir tidak bisa terurai secara biologis (non-biodegradable). Isu terbesar dari sampah plastik saat ini adalah 
mikroplastik yang terbawa di badan air, yang berasal dari fragmentasi atau pecahan dari plastik yang lebih besar (Cole et al., 2011; Wang et al., 2019). Di Indonesia sendiri, beberapa peneliti sudah meneliti tentang kandungan mikroplastik yang terdapat di sedimen di daerah pesisir yang terdiri atas bentuk fragmen, fiber dan filum (Aridhakahffi \& Ritonga, 2015 ; Khoironi et al., 2020 ; Firdaus et al., 2020). Penelitian terdahulu juga menemukan bahwa mikroplastik ini dapat tertelan oleh hewan laut dan menyebabkan beberapa masalah seperti sensitifitas terhadap makanan menurun, berpengaruh pada kemampuan bereproduksi dan juga menurunkan kecepatan berenang dari hewan air tersebut. (Yin et al., 2018 ;Cauwenberghe et al., 2013;Boerger et al., 2010)

Oleh karena itu, sampah plastik harus melalui pemrosesan sampah yang baik. Jika sampah plastik diolah dengan baik dari sumbernya, maka bukan hal tidak mungkin untuk memanfaatkan kembali sampah plastik tersebut sebagai barang yang lebih memiliki nilai guna. Namun sayangnya, sampah plastik dalam pembuangannya jarang dipilah terlebih dahulu. Kebanyakan dari masyarakat kita belum terbiasa memisahkan sampah sisa makanan, sampah plastik yang dapat di-recycle, dengan sampah lainnya yang tidak dapat di-recycle. Karena masyarakat cenderung untuk menggabungkan sampah ini dan langsung membuangnya di TPS terdekat, petugas kebersihan sering kewalahan untuk memilah sampah ini agar dapat dimanfaatkan sesuai dengan jenis sampah tersebut. Misalnya, sampah organik sisa makanan yang sudah dipilah dapat diolah dengan benar dan menghasilkan pupuk kompos. Sedangkan sampah plastik yang telah dipilah, dapat dimanfaatkan sebagai barang berguna lainnya, salah satunya yaitu ecobrick. Ecobrick sendiri adalah inovasi terbaru pemanfaatan sampah plastik yang dibuat dengan cara memotong sampah plastik menjadi bagian bagian kecil dan kemudian memadatkan sampah plastik yang tidak dapat terurai secara biologis (non-biodegradable) tersebut ke dalam botol minuman plastik bekas (The Global Ecobrick Alliance, 2018). Setelah dipadatkan, ecobricks dapat digunakan untuk membangun ruang-ruang hijau bagi masyarakat sekitar, furnitur unik seperti meja atau kursi, dan banyak lagi penggunaan praktis lainnya.

Sekolah anak merdeka Balikpapan atau biasa disingkat sebagai Sekar, adalah sebuah sekolah semi homeschooling. Sekolah ini memberikan inovasi pembelajaran baru yaitu memerdekakan anak untuk belajar, tidak terbatas pada jam - jam dan tugas tertentu. Di Sekar ini, anak-anak didiknya dimerdekakan untuk mengadakan riset atau belajar sesuai dengan bakat minat masing- masing anak didiknya. Sekar diisi oleh anak dari TK hingga campuran kelas 1,4,5 tingkat sekolah dasar (SD). Menjadi rumah bagi pembelajaran modern dan merdeka, Sekar menyediakan pembelajaran aquaponics, pengomposan dan penanaman tanaman. Di dalam proses pembelajaran di Rumah Belajar Sekar, tidak hanya murid yang ikut dalam proses pembelajaran, tapi orang tua wali murid, dan bahkan masyarakat yang haus akan ilmu juga diperkenankan untuk ikut belajar di sini. Tempat belajar yang berdiri pada jalan pondok karya agung ini, sangat peduli terhadap permasalahan lingkungan yang ada di Indonesia ini. Dalam rangka ikut bergerak pada penanganan sampah plastik, Yayasan Sekar Pelita Bangsa bekerjasama dengan unilever membuat drop box bagi warga pondok karya agung, Balikpapan, untuk meletakkan sampah bungkus plastik yang sudah dibersihkan dan dikeringkan pada drop box tersebut, seperti yang dapat dilihat pada gambar 1. Namun, sampah tersebut belum dimanfaatkan dengan baik. Di samping itu, Rumah Belajar Sekar saat ini akan mendirikan kelas khusus mengenai pendidikan peduli lingkungan atau yang biasa disebut sebagai ecoclass. Pada kelas ini, peserta didik akan diajarkan mengenai segala hal mengenai lingkungan, agar mereka memiliki kepedulian terhadap lingkungan sejak dini. Oleh karena itu, mereka membutuhkan furnitur berupa meja dan kursi.

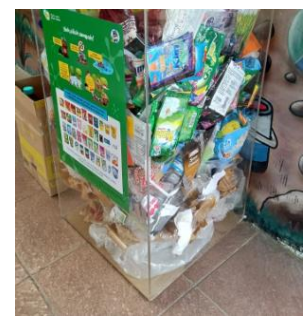

Gambar 1. Drop Box Sampah Plastik Bekas di Sekar

Tujuan dari pengabdian masyarakat ini adalah menyelesaikan permasalahan mitra dalam memenuhi kebutuhan furnitur untuk ecoclass, dengan memanfaatkan potensi adanya sampah bungkus plastik bekas yang diletakkan di drop box di Rumah Belajar Sekar. Tujuan ini dapat dicapai dengan cara mengadakan pelatihan pembuatan ecobrick dan juga membuat meja dan kursi dari ecobrick sebagai pemenuhan 
kebutuhan kegiatan belajar mengajar di rumah belajar sekar.

\section{METODE}

Pengabdian masyarakat ini dilaksanakan dengan dua metode, yaitu metode non-klasikal, melalui pelatihan dalam bentuk webinar dan metode klasikal dengan langsung membuat ecobrick di rumah belajar sekar yang terletak di jalan Pondok karya agung, RT 18 no. RB 80, Sungai Nangka, Kec. Balikpapan Selatan, Kota Balikpapan. Adapun langkah - langkah dalam pelaksanaan pengabdian masyarakat ini adalah:

1. Mengumpulkan data dan informasi

Pada kegiatan awal ini, dilakukan proses brainstorming ide untuk program yang akan dibuat. Pada fase ini, dilakukan pengumpulan data dan fakta informasi terkait.

2. Mengidentifikasi dan merumuskan masalah

Merupakan kegiatan menemukan dan mengidentifikasi permasalahan permasalahan berdasarkan fakta dan informasi yang telah dikumpulkan. Identifikasi ini dilakukan dengan cara yaitu studi literatur dan survei masyarakat sasaran. Studi literatur merupakan kegiatan mencari literatur yang dapat memperkuat alasan-alasan dalam gagasan ide program. Sedangkan survei masyarakat sasaran, merupakan kegiatan analisa kondisi masyarakat yang dituju melalui survei secara langsung, sehingga ditemukan permasalahan yang dialami mitra dan solusi apa yang dapat diberikan pada mitra.

3. Koordinasi dengan pihak terkait

Pada kegiatan ini, peneliti membuat kesepakatan dengan Sekar mengenai timeline diadakannya pelatihan pengelolaan sampah dan pelatihan pembuatan ecobrick, serta proses pembuatan ecobrick.

4. Persiapan alat dan bahan

Dikarenakan dalam pengabdian masyarakat ini akan diadakan pelatihan pembuatan ecobrick secara langsung melalui daring, maka perlu disiapkan alat dan bahan untuk membuat ecobrick yaitu botol air mineral bekas ukuran $650 \mathrm{~mL}$, sampah plastik bekas makanan ringan atau deterjen dan juga stik kayu dowel berukuran diameter $12 \mathrm{~mm}$ dengan panjang $40 \mathrm{~cm}$. Selain itu, untuk membuat furnitur dari ecobrick dan dinding dari ecobrick, membutuhkan alat dan bahan yaitu lem silikon beserta alat tembak lem silikon, isolasi bening, gunting, kawat loket, kabel ties, dan balok kayu.
5. Webinar pelatihan mengenai pengelolaan sampah dan pembuatan ecobrick

Webinar pelatihan mengenai pengelolaan sampah dan pembuatan ecobrick dilaksanakan secara daring dengan total peserta sebanyak 16 orang yang merupakan mahasiswa, siswa Rumah Belajar Sekar dan juga masyarakat umum. Pada webinar ini, dilakukan survei awal mengenai pola pengelolaan sampah rumahan peserta webinar yang terdiri dari anak didik sekar dan juga masyarakat umum yang berminat. Selain itu, di webinar ini diadakan survei awal mengenai pengetahuan peserta webinar mengenai ecobrick. Peneliti melakukan sosialiasi kepada peserta webinar mengenai bahaya sampah plastik, pentingnya memilah sampah, dan pentingnya membuang sampah pada tempatnya. Selain itu, memberikan pengenalan mengenai ecobrick, kemudian membuat pelatihan pembuatan ecobrick. Pada webinar ini, masyarakat diajarkan mengenai apa itu ecobrick, dan kesalahan kesalahan apa saja yang sering dilakukan saat membuat ecobrick. Selain itu, dalam era pandemi ini, peserta diingatkan untuk selalu mencuci bersih dan mengeringkan sampah plastik, sebelum dimasukkan ke dalam botol bekas untuk menjadi sebuah ecobrick. Di webinar ini juga dijelaskan bahwa ecobrick dapat dibentuk menjadi furnitur seperti meja dan kursi, namun jika ingin menjadikan ecobrick menjadi meja dan kursi, harus menggunakan botol plastik yang ukurannya sama. Selain itu, dijelaskan bahwa sampah medis tidak boleh dimasukkan ke dalam ecobrick ini, karena sampah medis merupakan sampah bahan berbahaya dan beracun (B3), yang pengelolaannya harusnya dilakukan secara khusus dan terpisah. Setelah dijelaskan, peneliti mempraktekkan secara langsung bagaimana membuat ecobrick menggunakan botol plastik bekas, bungkus plastik bekas dan juga kayu sebagai pendorong. Acara ini ditutup dengan tanya jawab dari peserta yang sangat antusias ingin membuat ecobrick dan ditutup dengan bermain kuis singkat. Di akhir acara juga diadakan survei akhir mengenai kepuasan peserta webinar mengenai isi pelatihan, dan juga minat dari peserta untuk membuat ecobrick.

6. Pembuatan furnitur untuk memfasilitasi rumah belajar Sekar

Untuk menjawab permasalahan mitra yang memiliki potensi sampah plastik untuk 
dijadikan ecobrick dan selaras dengan akan dibangunnya kelas ecoclass di rumah belajar sekar, peneliti berinisiatif untuk membuat ecobrick bersama timnya. Satu persatu botol ecobrick yang sudah jadi ini kemudian dikumpulkan, dipilah berdasarkan kepadatan isi. Total botol yang terkumpul adalah 104 botol, yang terkumpul beberapa dari anak didik Sekar, dan beberapa dari tim ecobrick. Botol - botol ecobrick yang padat, dikelompokkan dan disiapkan untuk dibentuk menjadi meja dan kursi menggunakan model segitiga dan heksagonal. Untuk membuat meja, dibutuhkan 12 botol yang dibentuk dengan model segitiga sebagai pondasi dasar dan 19 botol dengan model heksagonal untuk pondasi atas. Untuk membuat kursi, dibutuhkan 19 botol dengan model heksagonal. Botol-botol ecobrick yang tidak terlalu padat kemudian disatukan untuk dibentuk menjadi dinding pembatas kelas ecoclass ini. Rencana awal dari tahapan ini, sebelum dunia ditetapkan pada fase pandemi, tahap kegiatan terakhir ini, seharusnya dilakukan bersama-sama dengan anak didik Sekar dan juga masyarakat lainnya yang berminat. Namun, untuk menekan penyebaran virus COVID-19 ini, diputuskan bahwa pembuatan furnitur dan dinding dari ecobrick ini hanya dilakukan oleh tim pengabdian masyarakat yang beranggotakan 2 dosen dan 3 mahasiswa. Dengan mematuhi protokol kesehatan COVID-19, pembuatan furnitur ini dilakukan langsung di Rumah Belajar Sekar.

\section{HASIL DAN PEMBAHASAN}

\section{A. Webinar}

Pelatihan webinar ini dilakukan secara daring dan diikuti oleh 16 peserta dari Rumah Belajar Sekar dan juga masyarakat umum seperti yang dapat dilihat pada gambar 2 di bawah ini.

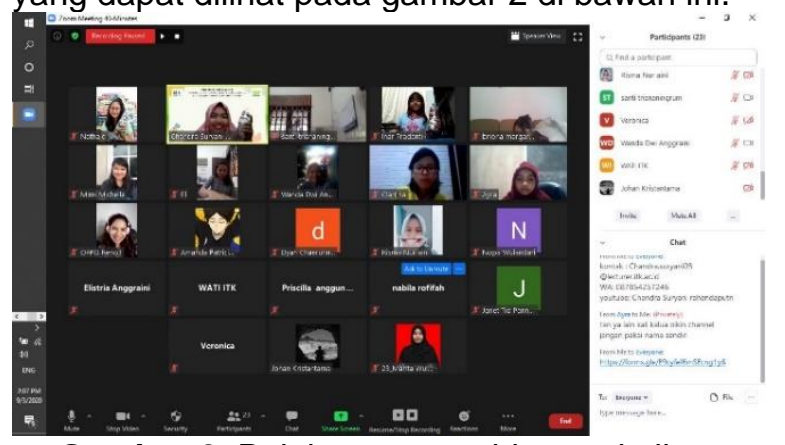

Gambar 2. Pelaksanaan webinar pelatihan pembuatan ecobrick bersama rumah belajar sekar
Di awal dan akhir webinar, dilakukan survei, dengan hasil di bawah ini:

\section{Pola pembuangan sampah peserta webinar}

Terjadi variasi frekuensi pembuangan sampah rumahan dari total 16 peserta, seperti yang digambarkan pada gambar 3 di bawah ini. $38 \%$ dari peserta membuang sampah 3-4 kali dalam seminggu, 37\% membuang sampah setiap hari dan $25 \%$ sisanya membuang sampah $1-2$ kali dalam seminggu. Dari total 17 peserta ini, tidak ada yang membuat sampah di frekuensi 5-6 kali dalam seminggu.

Frekuensi Membuang Sampah Rumahan

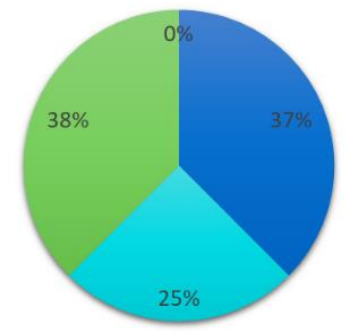

- Setiaphari $=1-2 \times$ seminggu $=3-4$ x seminggu $=5-6 x$ seminggu

Gambar 3. Hasil survei awal mengenai frekuensi membuang sampah rumahan

Dimana jumlah sampah yang dibuang dalam seminggu didominasi oleh seukuran kantong plastik ukuran $60 \times 80 \mathrm{~cm}$, yang dipilih oleh $69 \%$ peserta. Hal ini dapat dilihat dari gambar 4.

Kuantitas Sampah Yang Dibuang Dalam seminggu

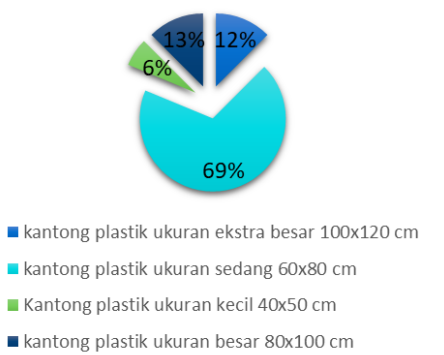

Gambar 4. Hasil survei awal mengenai kuantitas sampah yang dibuang peserta dalam seminggu

\section{Pola pemilahan sampah rumahan peserta webinar}

Sebanyak 10 orang peserta webinar sudah melakukan pemilahan sampah, dan sisanya tidak memilah sampah rumahan mereka, seperti yang dapat dilihat pada gambar 5. Dari 6 orang yang tidak memilah sampah mereka, 4 diantaranya menyatakan tidak memilah karena 
setelah dipilah tetap dibuang menjadi satu di TPS, sehingga mereka merasa sia - sia untuk memilah sampah mereka. 2 yang lain, memiliki alasan karena keterbatasan tempat sampah yang ada di rumah mereka.

Pola Pengelolaan Sampah

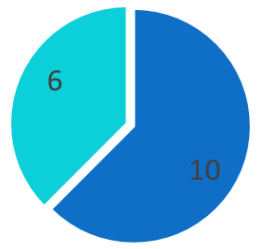

- Memilah Sampah (orang) = Tidak Memilah Sampah (orang)

Gambar 5. Hasil survei mengenai pengelolaan sampah yang dilakukan peserta di rumah mereka

3. Peningkatan pengetahuan mengenai ecobrick, sebelum dan setelah webinar berlangsung

Sebelum webinar berlangsung, dari survei awal didapatkan bahwa sebanyak 12 peserta dari 16 peserta sudah mengetahui apa itu ecobrick, seperti yang dapat dilihat pada gambar 6. Setelah webinar, dapat dilihat bahwa 16 peserta sudah mengetahui apa itu ecobrick, setelah webinar dilaksanakan. Oleh karena itu, dapat dilihat disini bahwa ada peningkatan pada pengetahuan peserta webinar mengenai ecobrick.

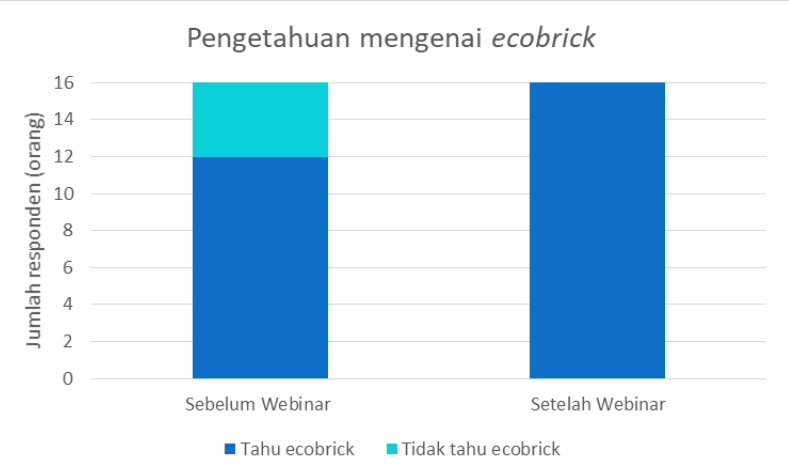

Gambar 6. Peningkatan pengetahuan mengenai ecobrick

Dari 12 peserta yang sudah mengetahui ecobrick tersebut, 9 diantaranya tahu manfaat dari ecobrick dan 3 lainnya masih belum mengetahui manfaat dari ecobrick, seperti yang dapat dilihat pada gambar 7. Setelah webinar berlangsung, sebanyak 16 peserta akhirnya mengetahui manfaat dari ecobrick.

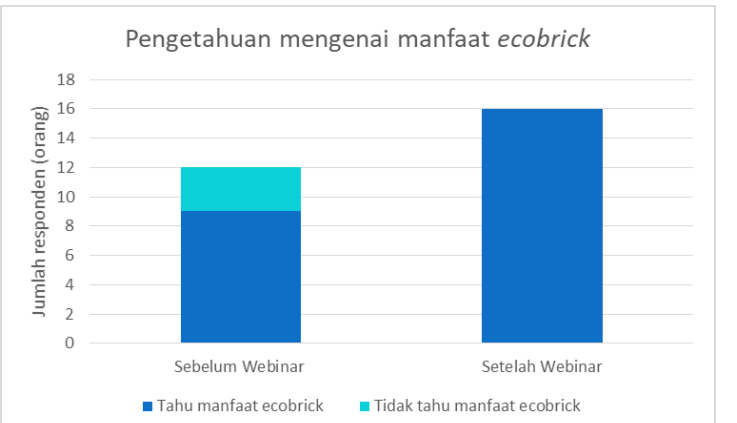

Gambar 7. Peningkatan pengetahuan manfaat ecobrick

4. Ketertarikan dalam ecobrick dan furnitur dari ecobrick setelah webinar

Setelah webinar berlangsung, dapat dilihat pada gambar 8 di bawah ini bahwa semua peserta menyatakan bahwa mereka tertarik untuk membuat ecobrick.

Ketertarikan membuat ecobrick

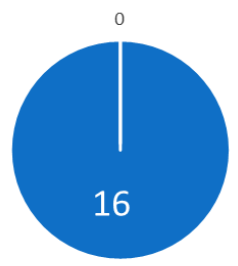

- Tertarik membuat ecobrick (orang)

- Tidak Tertarik membuat ecobrick (orang)

Gambar 8. Hasil survei ketertarikan membuat ecobrick setelah webinar

Namun dari 16 peserta ini, ada 2 peserta yang tidak tertarik untuk mengembangkan pemanfaatan ecobrick menjadi furnitur seperti meja dan kursi, yang dapat dilihat pada gambar 9 di bawah ini. Alasan dari 2 peserta yang tidak ingin membuat furnitur dari ecobrick ini adalah tidak ada waktu dan juga malas membuat. Hal ini disebabkan untuk membuat kursi dengan model heksagonal, diperlukan sebanyak 19 botol ecobrick, dimana untuk membuat 1 ecobrick bisa menghabiskan 1 hari 
Ketertarikan membuat furnitur dari ecobrick

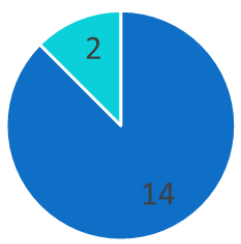

- Tertarik membuat furnitur dari ecobrick (orang)

- Tidak tertarik membuat furnitur dari ecobrick (orang)

Gambar 9. Hasil survei ketertarikan peserta untuk membuat furnitur dari ecobrick

\section{Kebermanfaatan pelatihan}

Dari hasil survei akhir yang dibagikan ke peserta setelah webinar, sebanyak 12 peserta merasa webinar pelatihan pembuatan ecobrick ini sangat bermanfaat, sedangkan 4 peserta lainnya merasa webinar ini bermanfaat, seperti yang dapat dilihat pada gambar 10 .

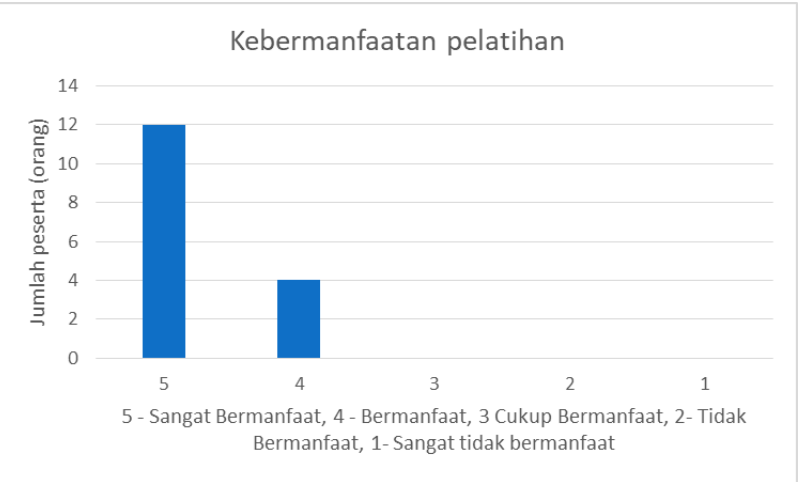

Gambar 10. Hasil survei mengenai kebermanfaatan pelatihan pembuatan ecobrick

\section{B. Pembuatan Furnitur dan Dinding Dari Ecobrick Di Rumah Belajar Sekar}

Untuk menjawab permasalahan mitra mengenai penyediaan furnitur untuk ecoclass, peneliti mengajak tim yang beranggotakan 2 dosen dan 3 mahasiswa Institut Teknologi Kalimantan, untuk membuat furnitur dari ecobrick langsung di Rumah Belajar Sekar (gambar 11).

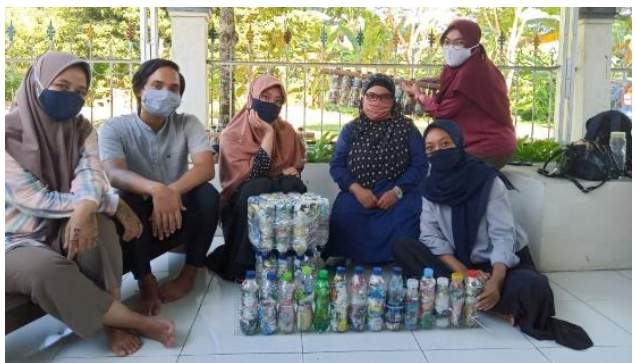

Gambar 11. Tim membuatkan furnitur dari ecobrick untuk rumah belajar sekar

Pada rencana awal, kegiatan ini seharusnya langsung melibatkan anak didik Sekar dan juga masyarakat sekitar untuk membuat furnitur ini bersama-sama, namun, karena dunia sekarang berada di era pandemi, maka peneliti memutuskan untuk membuat furnitur bersama tim ecobrick.

Dalam pembuatan furnitur ini, dari 104 botol yang terkumpul, terciptalah 2 kursi, 1 meja dan juga 3 dinding dari ecobrick. Dinding dari ecobrick ini hanya merupakan kerangka yang dapat dikembangkan lagi oleh Rumah Belajar Sekar untuk membuat pondasi yang lebih kokoh dalam pembangunan ecoclass. Hasil dari pembuatan furnitur ini dapat dilihat pada gambar 12 di bawah ini.

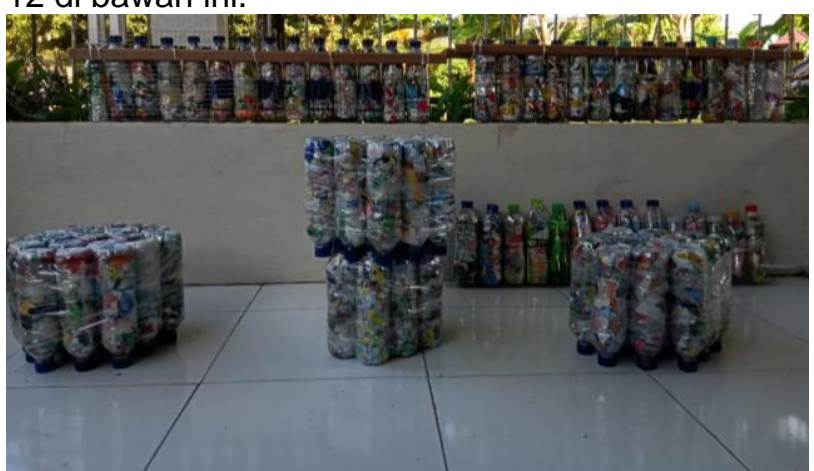

Gambar 12. Hasil furnitur yang dibuat tim ecobrick di rumah belajar sekar

\section{Kontribusi terhadap permasalahan sampah dan permasalahan mitra}

Sampah botol dan bungkus plastik yang digunakan dalam kegiatan ini, diambil dari sampah plastik yang diletakkan warga sekitar di drop box yang tersedia di Sekar. Oleh karena itu, ecobrick ini dapat menjawab tantangan untuk menabung sampah, agar tidak mencemari lingkungan, dan dapat diguakan untuk keperluan lainnya. Satu botol ecobrick ini dapat menampung setidaknya 180 gram sampah. Jika ada 100 botol tercipta, 18 kilogram sampah telah dilenyapkan dari tong sampah dan justru sampah ini kemudian 
disulap menjadi barang yang dapat dimanfaatkan untuk di rumah.

Ecobrick ini juga bisa menjawab kebutuhan mitra, yakni Yayasan Sekar Pelita Bangsa yang sedang butuh meja dan kursi untuk ecoclass mereka. Oleh karena itu, ecobrick ini merupakan sebuah jawaban untuk permasalahan sampah plastik dan juga permasalahan mitra.

\section{Kendala yang dialami selama melakukan kegiatan pengabdian masyarakat}

Pandemi menyebabkan peneliti tidak bisa praktek secara klasikal dan berinteraksi langsung dengan warga dan anak didik Rumah Belajar Sekar. Namun, dari hasil survei webinar, tujuan dari pengabdian masyarakat ini yaitu memberikan pengetahuan mengenai ecobrick sebagai salah satu upaya untuk mengelola sampah plastik masih tercapai dibuktikan dengan adanya peningkatan pengetahuan peserta mengenai ecobrick dan juga manfaat dari ecobrick itu sendiri. Selain itu, anak didik Rumah Belajar Sekar yang usianya beragam, ditambah juga dengan masyarakat umum yang mengikuti webinar ini, merupakan tantangan sendiri bagi peneliti untuk dapat memberikan pelatihan yang dapat diterima di semua kalangan usia.

\section{E. Rencana keberlanjutan program}

Dinding dari ecobrick sebenarnya dapat dikembangkan lebih lanjut dengan ditambahkan semen untuk benar-benar menjadi dinding. Sayangnya, di dalam tim pengabdian masyarakat ini, memiliki pengetahuan yang minim mengenai bangunan, sehingga tim ecobrick tidak dapat melanjutkan sampai benar-benar membangun tembok yang kokoh untuk Rumah Belajar Sekar. Selain itu, dari hasil interaksi pada saat webinar, banyak peserta yang mengeluh tentang pemotongan sampah menjadi bagian-bagian kecil. Memotong sampah menjadi bagian-bagian kecil, menurut peserta, sangat menyita banyak waktu. Walaupun kegiatan ini menyenangkan dan dapat menjadi kegiatan bersama keluarga di rumah, namun ternyata kegiatan memotong sampah ini merupakan salah satu bagian yang paling membuat malas peserta webinar untuk membuat ecobrick. Oleh karena itu, peneliti tertarik untuk kedepannya merancang alat pencacah sampah plastik rumahan pada penelitian dan kemudian jika berhasil, dapat dipraktekkan dengan masyarakat pada pengabdian masyarakat yang akan datang.

\section{SIMPULAN DAN SARAN}

Kegiatan membuat ecobrick ini dapat menjadi kegiatan keluarga yang menyenangkan pada saat pandemi COVID-19 ini. Selain itu, ecobrick ini dapat menjadi sebuah tabungan sampah plastik dan dapat dimanfaatkan untuk kedepannya sebagai furnitur atau bahkan bahan untuk membuat sebuah bangunan sederhana. Dari hasil webinar dapat diketahui bahwa sebenarnya sudah banyak masyarakat yang mengenal ecobrick. Namun beberapa tidak tahu manfaat dari ecobrick ini. Walaupun kegiatan membuat ecobrick ini sangat bermanfaat dan menyenangkan, ternyata banyak masyarakat yang merasa keberatan pada tahapan memotong sampah plastik menjadi bagian-bagian kecil. Oleh karena itu, untuk pengembangan pada dunia ecobrick ini dapat dikembangkan kepada penelitian untuk merancang alat pencacah sampah plastik skala rumahan yang dapat membantu masyarakat untuk mencacah sampah plastik dengan lebih nyaman. Selain itu, penggunaan yang lebih tinggi dari ecobrick adalah untuk bahan bangunan, namun karena tim masih belum memiliki kemampuan pada rancang bangun, sehingga tidak dapat dilanjutkan ke jenjang lebih tinggi. Untuk pengabdian masyarakat berikutnya, peneliti dapat mengajak anggota tim yang memiliki kemampuan rancang bangun dan berkonsentrasi lebih pada pemanfaatan ecobrick sebagai bahan bangunan sederhana.

\section{UCAPAN TERIMA KASIH}

Terima kasih kepada Lembaga Penelitian dan Pengabdian Masyarakat Institut Teknologi Kalimantan (LPPM ITK) yang telah mendanai kegiatan ini. Di samping itu, terima kasih kepada yayasan sekar pelita bangsa atau rumah belajar sekar, yang telah berkontribusi secara aktif mendukung kegiatan pengabdian masyarakat ini.

\section{DAFTAR RUJUKAN}

Aridhakahffi, I., \& Ritonga, I. ramadhan. (2015). Distribusi mikroplastik pada sedimen di Muara Badak, Kabupaten Kutai Kartanegara. Depik, 4(3), 121-131.

Boerger, C. M., Lattin, G. L., Moore, S. L., \& Moore, C. J. (2010). Plastic ingestion by planktivorous fishes in the North Pacific Central Gyre. Marine Pollution Bulletin, 60(12), 2275-2278.

Cauwenberghe, L. Van, Claessens, M., Vandegehuchte, M. B., Janssen, C., \& Mees, J. (2013). Assessment of marine 
debris on the Belgian Continental Shelf. Marine Pollution Bulletin, 73(1).

Cole, M., Lindeque, P., Halsband, C., \& Galloway, T. S. (2011). Microplastics as contaminants in the marine environment: A review. Marine Pollution Bulletin, 62, 2588-2597.

Firdaus, M., Trihadiningrum, Y., \& Lestari, P. (2020). Microplastic pollution in the sediment of Jagir Estuary, Surabaya City, Indonesia. Marine Pollution Bulletin, 150.

Kementerian Lingkungan Hidup dan Kehutanan Republik Indonesia. (2018). Komposisi sampah di Balikpapan.

Khoironi, A., Hadiyanto, H., Anggoro, S., \& Sudarno, S. (2020). Evaluation of polypropylene plastic degradation and microplastic identification in sediments at Tambak Lorok coastal area, Semarang, Indonesia. Marine Pollution Bulletin, 151.

The Global Ecobrick Alliance. (2018). What is ecobrick.

https://www.ecobricks.org/what/

Wang, J., Liu, X., Li, Y., Powell, T., Wang, X., Wang, G., \& Zhang, P. (2019). Microplastics as contaminants in the soil environment: A mini-review. Science of the Total Environment, 691, 848-857. https://doi.org/10.1016/j.scitotenv.2019.0 7.209

Yin, L., Chen, B., Xia, B., Shi, X., \& Qu, K. (2018). Polystyrene microplastics alter the behavior, energy reserve and nutritional composition of marine jacopever (Sebastes schlegelii). Journal of Hazardous Materials, 360, 97-105. 